\title{
Too bad! Fixed dose combination antiretroviral drugs
}

\author{
Thomas Agyarko-Poku ${ }^{1 *}$, Yaw Adu Sarkodie², Linda Atakorah-Yeboah ${ }^{3}$ \\ From International Symposium HIV and Emerging Infectious Diseases 2014 \\ Marseille, France. 21-23 May 2013
}

\section{Introduction}

Pill burden is a factor for non-adherence to Antiretroviral drugs (ARVs). The introduction of Fixed Dose Combination ARVs regime is seen as an antidote to pill burden among HIV patients on treatment. The study hypothesized that not all HIV patients will accept this new regime, and was conducted to determine their perception on the new treatment regime.

\section{Materials and methods}

1681 HIV positive patients accessing care at Suntreso STI/HIV Clinic in Kumasi, who have been on treatment for more than 12 months and consented to participate were recruited for this cross sectional study. They were interviewed using semi-structured pre-texted questionnaire prior to the commencement of the new fixed dose combination ARVs treatment regime. Data was entered and analyzed using SPSS version 16.

\section{Results}

Whereas, $60.9 \%(1023 / 1681)$ find the present dose regime cumbersome, $39.1 \%(657 / 1681)$ of the patients prefer the multiple dose regime. $42.2 \%$ (709) of respondents have some reservations about fixed dose combination regime whilst $24.6 \%$ (413) prefer it, with $33.3 \%$ (559) being in different. Reasons for the reservation included; 'Side effect may be too serious' (48.3\%, 342/709), 'Virus too powerful for a single molecule' $(30.2 \%, 214 / 709)$, 'Attempt to deprive us of drugs and facilitate our death' (13.8\%, 92/ 709) and 'Cost of drugs will be expensive in future for a combine drugs therapy' $(7.7 \%, 55 / 709)$.

\section{Conclusions}

Although, majority of patients find the multiple dose regimes cumbersome, they are skeptical about the use

${ }^{1}$ Suntreso Government Hospital, Ghana Health Services, Kumasi, Ghana Full list of author information is available at the end of the article of the fixed dose combination treatment regime. The new regime may result in overdosing if they find it inadequate to provide the needed protection. The fear of serious adverse reaction from combination of ARVs compared with separate drugs may scare them from taking the treatment. Intensive adherence counseling taking care of the above concerns is essential before patients are switched onto the fixed dose ARV regime.

\section{Authors' details}

${ }^{1}$ Suntreso Government Hospital, Ghana Health Services, Kumasi, Ghana.

${ }^{2}$ Department of Clinical Microbiology, School of Medical Sciences, University of Science and Technology, Kumasi, Ghana. ${ }^{3}$ Manhyia Government Hospital, Ghana Health Services, Kumasi, Ghana.

Published: 23 May 2014

\section{doi:10.1186/1471-2334-14-S2-P80}

Cite this article as: Agyarko-Poku et al:: Too bad! Fixed dose combination antiretroviral drugs. BMC Infectious Diseases 2014 14(Suppl 2):P80.

Submit your next manuscript to BioMed Central and take full advantage of:

- Convenient online submission

- Thorough peer review

- No space constraints or color figure charges

- Immediate publication on acceptance

- Inclusion in PubMed, CAS, Scopus and Google Scholar

- Research which is freely available for redistribution 